\title{
Interleukin-28B Genetic Variants and Peripheral Blood Interferon Receptor 2
}

Koji Ishii*, Mie Shinohara, Kaori Kanayama, Michio Kogame, Misato Shiratori and Yasukiyo Sumino

Division of Gastroenterology and Hepatology, Department of Internal Medicine, Toho University School of Medicine, Toho University, 6-11-1, Omorinishi, Otaku, Tokyo 143-8541, Japan

\section{Abstract}

Background/Aims: Genetic variation in the interleukin 28B (IL-28B) region has been associated with sustained virological response (SVR) rates in patients with chronic hepatitis $\mathrm{C}(\mathrm{CHC})$ who were treated with pegylatedinterferon (PEG-IFN) and ribavirin (RBV). The aim of this study is to clarify whether changes in type $1 \mathrm{IFN}$ receptor 2 (IFNAR-2) expressions by peripheral blood monocytes (Mo) are related to genetic variation near the IL-28B gene.

Patients and Methods: One hundred and forty-eight $\mathrm{CHC}$ patients with genotype $1 \mathrm{~b}$ and high viral load receiving PEG-IFN and RBV were studied. IFNAR-2 expression by peripheral blood Mo was measured as the mean fluorescence intensity (MFI) before and up to 28 days after starting therapy. Eighty-three of 148 patients consented to genetic investigation (IL-28B genetic variants in rs8099917).

Results: There were no significant differences in MFI of peripheral blood Mo between SVR and non-SVR patients during the study period in patients with genotype TT in rs8099917; however, MFI of peripheral blood Mo at days 7 and 14 of treatment was significantly higher in SVR patients than in non-SVR patients with genotype TG in rs8099917.

Conclusions: IFNAR-2 may be related to efficacy of PEG-IFN and RBV in CHC patients possessing poorresponse IL-28B variants.

Keywords: Chronic hepatitis C; Interleukin-28B; Type 1 interferon receptor 2; Peripheral blood monocyte Genotype $1 \mathrm{~b}$

\section{Introduction}

Infection with hepatitis $\mathrm{C}$ virus (HCV) is a global health problem. Chronic infection with HCV is risk factor for related morbidity and mortality from liver cirrhosis and hepatocellular carcinoma. Curative antiviral therapy may prevent these complications, and the current standard of care is pegylated-interferon alpha (PEG-IFN alpha) and ribavirin (RBV) combination therapy for chronic hepatitis $\mathrm{C}(\mathrm{CHC})$. However, of patients infected with genotype $1 \mathrm{~b}$, the most common HCV, only approximately $40-50 \%$ are cured by this therapy $[1,2]$.

A number of pretreatment host and viral factors have been associated with treatment outcome in patients with CHC. These include age, sex, body mass index, insulin resistance, hepatic steatosis, hepatic fibrosis and baseline viral load, as well as amino acid (aa) mutations in the HCV core region and the number of aa mutations in the IFN sensitivity region (ISDR). Recently, Tanaka et al. showed that genetic variations near the IL-28 gene (rs8099917) on chromosome 19 are host-related factors that encode IFN lambda3, and are pretreatment predictors of virological response to 48 -week PRG-IFN plus RBV combination therapy in Japanese CHC patients infected with HCV genotype $1 \mathrm{~b}$ and having high viral loads [3].

We have been using a rapid flow cytometry method for measuring type 1 IFN receptor-2 (IFNAR-2). We recently reported that serial changes in IFNAR-2 expression by peripheral blood monocytes (Mo) are associated with early virologic response (EVR) in CHC patients infected genotype $1 \mathrm{~b}$ and high viral load treated with IFN-based therapy [4], as intracellular signaling is initiated after the binding of IFN to INFAR-2 on the plasma membrane of target cells. However, it is uncertain how IFNAR-2 expressed by peripheral blood Mo differs between patients treated with PEG-IFN alpha-2b and -2a in combination with RBV, and how IL-28B genetic variants influence expression of IFNAR-2 by peripheral blood Mo in $\mathrm{CHC}$ patients treated with PEG-IFN and RBV.
The aim of the present study was to clarify whether changes in IFNAR-2 expression by peripheral blood Mo up to day 28 of IFN treatment differed between patients treated with PEG-IFN alpha-2a and $-2 b$ in combination with RBV, and whether these changes differ between patients with IL-28B genetic variants.

\section{Patients and Methods}

\section{Patients}

From patients with CHC who received PEG-IFN alpha-2a or -2b in combination with RBV, treated at our hospital between January 2005 and June 2010, and in whom IFNAR-2 expression by peripheral blood Mo was measured, 148 consecutive patients were selected. All patients were positive for anti-HCV antibody on third-generation enzymelinked immunosorbent assay (ELISA) and for serum HCV-RNA quantified on COBAS TaqMan HCV test (Chugai Pharmaceutical Co. Ltd., Tokyo, Japan; lower detection limit: 1.2 log copies/ml, upper limit $7.8 \mathrm{log}$ copies/ml). Serum levels of HCV-RNA in the subjects ranged (10th-90th percentiles) from 5.1 to 6.9 (median: 6.4) log copies $/ \mathrm{ml}$.

Enrollment criteria for patients with CHC (88 men and 60 women)

*Corresponding author: Koji Ishii, Division of Gastroenterology and Hepatology Department of Internal Medicine, Toho University School of Medicine, Toho University, 6-11-1, Omorinishi, Otaku, Tokyo 143-8541, Japan, Tel: +81-3-3762 4151; Fax: +81-3-3763-8542; E-mail: iskoji377@med.toho-u.ac.jp

Received June 07, 2012; Accepted June 18, 2012; Published June 20, 2012

Citation: Ishii K, Shinohara M, Kanayama K, Kogame M, Shiratori M, et al. (2012) Interleukin-28B Genetic Variants and Peripheral Blood Interferon Receptor 2. J Blood Lymph 2:108. doi:10.4172/2165-7831.1000108

Copyright: (C) 2012 Ishii K, et al. This is an open-access article distributed unde the terms of the Creative Commons Attribution License, which permits unrestricted use, distribution, and reproduction in any medium, provided the original author and source are credited. 
included age ranging (10th-90th percentiles) from 41 to 66 years (median: 56 years). All patients were infected with HCV genotype $1 b$, and received a course of therapy with PEG-IFN alpha- $2 a$ or $-2 b$ in combination with RBV. Patients who were known to be homosexual or intravenous drug users, those positive for hepatitis B surface antigen (HBs-Ag) or antinuclear antibody, and those with metabolic liver dysfunction or renal dysfunction were excluded.

Of the 148 patients, 102 patients had undergone percutaneous liver biopsy before combination therapy under ultrasonographic control, and the tissue specimens thus obtained were graded according to the Histology Activity Index (HAI) of Knodell et al. [5], after which the specimens were divided into three groups according to Desmet [6]: Grade 1 for HAI scores of 1-3, Grade 2 for HAI scores of 4-8, and Grade 3 for HAI scores of 9 or more. Specimens were also divided into four groups from stage 1 to stage 4 based on Desmet fibrosis scores [6].

\section{IFN regimens}

After providing informed consent, 55 patients received PEGIFN alpha-2a (Pegasys $^{\circledR}$, Chugai Pharmaceutical Co., Ltd., Japan) for a median of 48 (ranging 10th - 90th percentiles: 48 - 72) weeks at a weekly dose of $180 \mathrm{ug}$. Ninety-three patients received PEG-IFN alpha-2b (PegIntron ${ }^{\circledR}$, Schering Plough Co., Ltd., Japan) for a median of 48 (ranging 10th - 90th percentiles: 48 - 72) weeks at weekly doses adjusted for body weight according to the manufacturer's instructions ( $45 \mathrm{~kg}$ or less=60 ug/dose, 46 to $60 \mathrm{~kg}=80 \mathrm{ug} /$ dose, 61 to $75 \mathrm{~kg}=100 \mathrm{ug} /$ dose, 76 to $90 \mathrm{~kg}=120 \mathrm{ug} /$ dose, and 91 or more $=150 \mathrm{ug} / \mathrm{dose}$ ).

RBV (Rebetol ${ }^{\circledR}$, Schering Plough Co., Ltd., or Copegus ${ }^{\circledR}$, Chugai Pharmaceutical Co., Ltd.) was given orally at daily doses adjusted for body weight according to the manufacturer's instructions $(60 \mathrm{~kg}$ or less $=600 \mathrm{mg} / \mathrm{day}, 61$ to $80 \mathrm{~kg}=800 \mathrm{mg} / \mathrm{day}$, and $81 \mathrm{~kg}$ or more $=1,000$ $\mathrm{mg} /$ day) for a median of 48 (ranging 10th-90th percentiles: 48-72) weeks.

Some patients needed slight adjustment of the PEG-IFN and RBV doses, because of a decrease in leukocyte count, platelet count, or hemoglobin during therapy.

\section{Viral kinetic study}

Serum HCV-RNA was measured using the COBAS TaqMan HCV test before and every 4 weeks thereafter until the end of therapy, as well as at 24 weeks after the end of therapy.

If serum HCV-RNA by COBAS TaqMan HCV test was negative or showed a $2 \log$ drop in week 12, this was defined as an EVR. If serum HCV-RNA by COBAS TaqMan HCV test was positive or showed a less than $2 \log$ drop in week 12, this was defined as a non-EVR.

Sustained viral response (SVR) was defined as being negative for serum HCV-RNA by COBAS TaqMan HCV test at 24 weeks after the end of therapy. Other patterns were non-SVR, including non-responder (serum HCV-RNA levels detectable after completed treatment period) and relapsed responder patients (undetectable serum HCV-RNA during therapy, but detectable after discontinuation).

\section{Genetic variations in IL28B gene}

Of 148 CHC patients, 83 consented to genetic testing, and genetic variations in IL-28B were thus analyzed. The region on chromosome 19 associated with HCV treatment response contains multiple singlenucleotide polymorphisms (SNPs) in linkage disequilibrium around the IL28B gene. Whole blood samples for a genome-wide association survey were genotyped using the Illumina HumanHap610-Quad Genotyping
BredCrip. Genotyping for replication and fine mapping was performed using Invador assay, TaqMan assay, or direct sequencing, as described previously $[7,8]$. In this study, genetic variations near the IL-28B gene (rs 8099917), reported as pretreatment predictors of treatment efficacy and clinical outcome in Japanese, were investigated [3].

\section{Assays}

Blood samples were collected from all patients before and at 3, 7, 14 and 28 days after the start of IFN therapy. IFNAR-2 expression by peripheral leukocytes was then determined by flow cytometry to measure the mean fluorescence intensity (MFI) after staining with anti-IFNAR-2 antibody, as reported previously [9].

Serum levels of alanine aminotransferase (ALT) and aspartate aminotransferase (AST) were measured according to standard procedures. Peripheral blood leukocyte count (WBC), red blood cell count (RBC), hemoglobin (Hgb) and platelet count (PLT) were also measured according to standard procedures.

\section{Comparisons performed}

As genotype GG IL-28B was not detected in CHC patients, patients were divided into 2 groups; patients with IL-28B genotype TT $(n=56)$ and those with IL-28B genotype TG $(\mathrm{n}=27)$.

We investigated the following:

1. Comparison of IFNAR-2 expression in peripheral blood Mo between patients treated with PEG-IFN alpha-2a and $-2 b$ in combination with RBV.

2. Comparison of clinical backgrounds and efficacy of PEG-IFN and RBV therapy between patients with genotype TT and genotype TG in rs 8099917.

3. Comparison of IFNAR-2 expression in peripheral blood Mo in EVR, non-EVR, SVR and non-SVR patients who had genotypes TT and TG in rs 8099917.

\section{Statistical analysis}

Results are presented as medians and 10th-90th percentiles. Chi square test was used to compare characteristics between the groups.

Data shown in the figures are expressed as means \pm S.D. Comparisons between the 2 groups were performed by nonparametric Mann-Whitney test or chi square test. Probability values of less than 0.05 were considered to indicate statistical significance.

\section{Results}

\section{Comparison of PEG-IFN alpha 2a and PEG-IFN alpha 2b}

Pretreatment outcome did not differ between patients treated with PEG-IFN alpha-2a and those treated with PEG-IFN alpha-2b in combination with RBV (Table 1), nor were there any significant differences in IFNAR-2 expression by peripheral blood Mo during the study period between these patient groups (Figure 1).

\section{Viral kinetics between patients with genotype TT and TG in rs8099917}

Pretreatment outcome of patients with genotype TT and TG are not different except age (Table 2).

Of 56 patients, 55 (98\%) with IL-28 genotype TT showed EVR, while 15 of 27 patients (56\%) with IL-28 genotype TG showed EVR. 
Citation: Ishii K, Shinohara M, Kanayama K, Kogame M, Shiratori M, et al. (2012) Interleukin-28B Genetic Variants and Peripheral Blood Interferon Receptor 2. J Blood Lymph 2:108. doi:10.4172/2165-7831.1000108

Page 3 of 5

In addition, 35 of 56 patients (63\%) with IL-28B genotype TT achieved SVR, while 5 of 27 patients (19\%) with genotype TG achieved SVR. The rates for EVR and SVR were significantly different $(\mathrm{P}<0.01$ on chi square test) between the 2 groups (Table 3 ).

\section{IFNAR-2 expression in IL-28B genetic variants}

IFNAR-2 expression by peripheral blood Mo was higher in patients with genotype TT than in patients with genotype TG throughout the study period, although statistical significance was not reached (Figure 2).

\section{IFNAR-2 expression in EVR and non-EVR patients with IL-} $28 \mathrm{~B}$ genetic variants

IFNAR-2 expression by peripheral blood Mo was significantly higher at days 3 and 14 of treatment in EVR patients than in non-EVR patients with IL-28 genotype TG (Figure 3). Because only 1 patient did not show EVR, statistical evaluation could not be performed between EVR and non-EVR patients with IL-28 type genotype TT.

\begin{tabular}{|c|c|c|c|}
\hline & PEG-IFN alpha $2 a$ & PEG-IFN alpha $2 b$ & $P$ value \\
\hline $\begin{array}{l}\text { No. of patients }(n=) \\
\text { Age (y.o.) } \\
\text { Sex (M/F) } \\
\text { II-28B (TT/TG/none) }\end{array}$ & $\begin{array}{l}55 \\
\text { Median: } 56 \\
\text { (range: } 43-66 \text { ) } \\
32 / 23 \\
24 / 7 / 24\end{array}$ & $\begin{array}{l}93 \\
\text { Median: } 55 \\
\text { (range: } 41-66 \text { ) } \\
56 / 37 \\
32 / 20 / 41\end{array}$ & $\begin{array}{l}\text { NS } \\
\text { NS } \\
\text { NS }\end{array}$ \\
\hline $\begin{array}{l}\text { Serum } \\
\text { HCV-RNA (Log copies / ml) } \\
\text { AST (IU/ml) } \\
\text { ALT (IU/ml) }\end{array}$ & $\begin{array}{l}\text { Median: } 6.4(5.3-7.1) \\
\text { Median: } 55(29-89) \\
\text { Median: } 55(30-125)\end{array}$ & $\begin{array}{l}\text { Median: } 6.5(5.5-6.9) \\
\text { Median: } 56(27-136) \\
\text { Median: } 68(35-188)\end{array}$ & $\begin{array}{l}\text { NS } \\
\text { NS } \\
\text { NS }\end{array}$ \\
\hline $\begin{array}{l}\text { Peripheral Blood } \\
\text { WBC }(/ \mu \mathrm{l}) \\
\text { RBC }\left(\times 10^{4} / \mu \mathrm{l}\right) \\
\text { PLT }\left(X 10^{4} / \mu \mathrm{l}\right)\end{array}$ & $\begin{array}{l}\text { Median: } 5600 \\
\text { (4120-7160) } \\
\text { Median: } 459(410-505) \\
\text { Median 14.7: (3.3-15.9) }\end{array}$ & $\begin{array}{l}\text { Median: } 4500 \\
\text { (3650-6740) } \\
\text { Median: 445(404-503) } \\
\text { Median: 14.2(12.3-15.8) }\end{array}$ & $\begin{array}{l}\text { NS } \\
\text { NS } \\
\text { NS }\end{array}$ \\
\hline $\begin{array}{l}\text { Pathological findings } \\
\text { Activity }(1 / 2 / 3 / \text { none }) \\
\text { Fibrosis (1/2/3/4/none) }\end{array}$ & $\begin{array}{l}16 / 19 / 1 / 19 \\
12 / 13 / 4 / 7 / 19\end{array}$ & $\begin{array}{l}31 / 33 / 2 / 27 \\
24 / 24 / 10 / 8 / 27\end{array}$ & $\begin{array}{l}\text { NS } \\
\text { NS }\end{array}$ \\
\hline
\end{tabular}

Ranges represent the $0^{\text {th }}$ to $100^{\text {th }}$ percentile.

Table 1: Background of patients treated with PEG-IFN alpha-2a and $-2 b$ in combination with ribavirin.

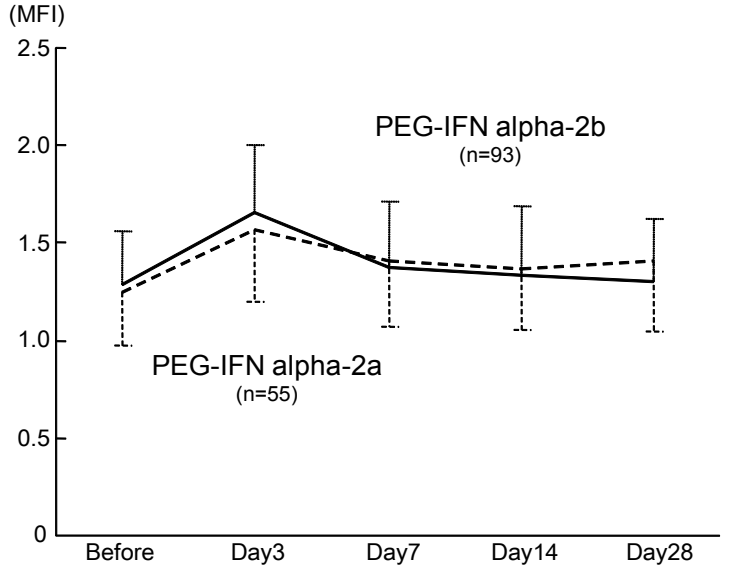

Figure 1: The solid line shows mean IFNAR-2 expression by peripheral blood Mo (+ S.D.) in patients treated with PEG-IFN alpha-2b and ribavirin (RBV). The dotted line shows mean IFNAR-2 expression by Mo (- S.D.) in patients treated with PEG-IFN alpha-2b and RBV. There were no significant differences between the groups.

\section{IFNAR-2 expression in SVR and non-SVR patients with IL- 28B genetic variants}

There were no statistical differences in IFNAR-2 expression based on peripheral blood Mo between SVR and non-SVR patients with IL28 type genotype TT (Figure 4A).

IFNAR-2 expression by peripheral blood Mo was significantly higher at days 7 and 14 of treatment in SVR patients than in non-SVR patients with IL-28 type genotype TG (Figure 4B).

\begin{tabular}{|c|c|c|c|}
\hline & TT rs 8099917 & TG rs8099917 & $P$ value \\
\hline $\begin{array}{l}\text { No. of patients }(n=) \\
\text { Age (y.o.) } \\
\text { Sex (M/F) }\end{array}$ & $\begin{array}{l}56 \\
\text { Median: } 57 \\
\text { (range:44 - 65 ) } \\
37 / 19\end{array}$ & $\begin{array}{l}27 \\
\text { Median: } 49 \\
\text { (range: } 41-63 \text { ) } \\
15 / 12\end{array}$ & $\begin{array}{l}<0.04 \\
\text { NS }\end{array}$ \\
\hline $\begin{array}{l}\text { Serum } \\
\text { HCV-RNA (Log copies/ml) } \\
\text { AST (U/L) } \\
\text { ALT (U/L) }\end{array}$ & $\begin{array}{l}\text { Median: } 6.7 \\
(5.5-7.1) \\
\text { Median: } 52 \\
(25-128) \\
\text { Median: } 68 \\
(9-351)\end{array}$ & $\begin{array}{l}\text { Median: } 6.5 \\
(5.6-6.8) \\
\text { Median: } 44 \\
(20-123) \\
\text { Median: } 51 \\
(16-301)\end{array}$ & $\begin{array}{l}\text { NS } \\
\text { NS } \\
\text { NS }\end{array}$ \\
\hline 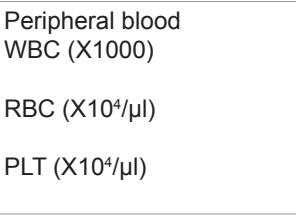 & $\begin{array}{l}\text { Median: } 4850 \\
(3600-7300) \\
\text { Median: } 448 \\
(386-519) \\
\text { Median: } 15.6 \\
(9.5-22.0)\end{array}$ & $\begin{array}{l}\text { Median: } 4950 \\
(3400-6900) \\
\text { Median: } 444 \\
(328-496) \\
\text { Median: } 17.8 \\
(12.0-24.0)\end{array}$ & $\begin{array}{l}\text { NS } \\
\text { NS } \\
\text { NS }\end{array}$ \\
\hline $\begin{array}{l}\text { Pathological findings } \\
\text { Activity }(1 / 2 / 3 / \text { none }) \\
\text { Fibrosis (1/2/3/4/none) }\end{array}$ & $\begin{array}{l}15 / 18 / 1 / 22 \\
11 / 13 / 5 / 5 / 22\end{array}$ & $\begin{array}{l}12 / 10 / 1 / 4 \\
8 / 10 / 2 / 3 / 4\end{array}$ & $\begin{array}{l}\text { NS } \\
\text { NS }\end{array}$ \\
\hline
\end{tabular}

Table 2: Backgrounds of patients with IL-28 variants.

\begin{tabular}{|c|c|c|c|}
\hline & TT rs 8099917 & TG rs8099917 & $P$ value \\
\hline $\begin{array}{l}\text { No. of patients }(n=) \\
\text { Kind of PEG-IFN } \\
(-2 a /-2 b) \\
\text { Period of therapy(weeks) }\end{array}$ & $\begin{array}{l}56 \\
32 \text { / } 24 \\
\text { Median: } 48 \\
(48-72)\end{array}$ & $\begin{array}{l}27 \\
20 / 7 \\
\text { Median: } 48 \\
(24-72)\end{array}$ & $\begin{array}{l}\text { NS } \\
\text { NS }\end{array}$ \\
\hline $\begin{array}{l}\text { Efficacy of therapy } \\
\text { EVR/non-EVR } \\
\text { SVR/non-SVR }\end{array}$ & $\begin{array}{l}55 / 1 \\
35 / 21\end{array}$ & $\begin{array}{l}15 / 12 \\
5 / 22\end{array}$ & $\begin{array}{l}<0.01 \\
<0.01\end{array}$ \\
\hline
\end{tabular}

Ranges represent the $0^{\text {th }}$ to $100^{\text {th }}$ percentile.

Table 3: Backgrounds of patients with IL-28 variants and therapeutic efficacy.

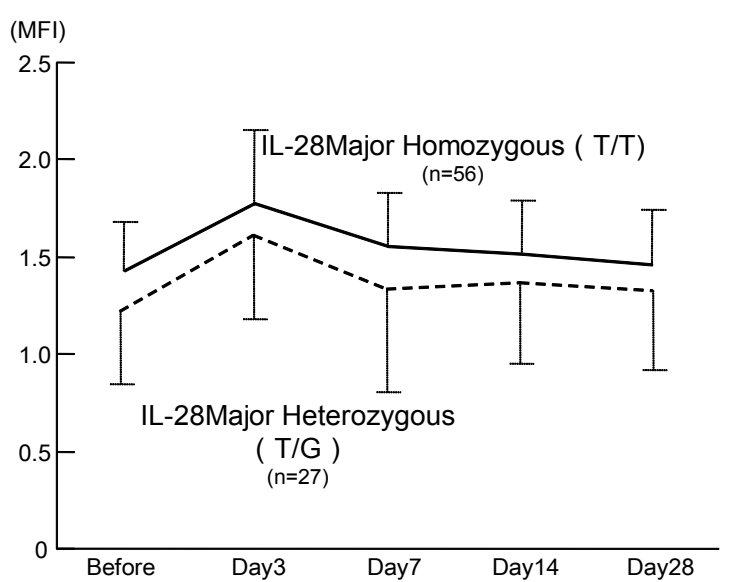

Figure 2: The solid line shows mean IFNAR-2 expression by peripheral blood Mo (+ S.D.) in patients with IL-28 genotype TT, while the dotted line shows mean IFNAR-2 expression by Mo (- S.D.) in patients with IL-28 genotype TG. There were no significant differences between the groups. 


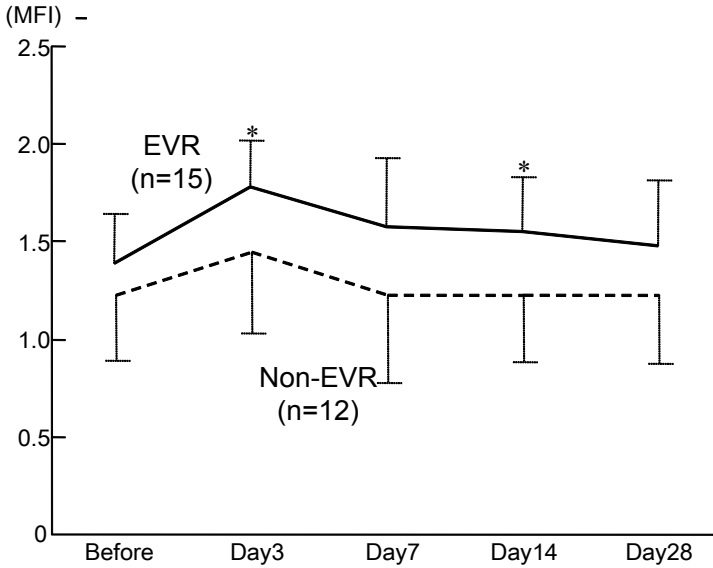

Figure 3: The solid line shows mean IFNAR-2 expression by peripheral blood Mo (+ S.D.) in patients with IL-28 genotype TG who achieved EVR, while the dotted line shows IFNAR-2 expression by Mo (- S.D.) in patients with IL-28 genotype TG who were non-EVR.

*: Significant difference $(P<0.05)$ between EVR and non-EVR patients with IL28 genotype TG.

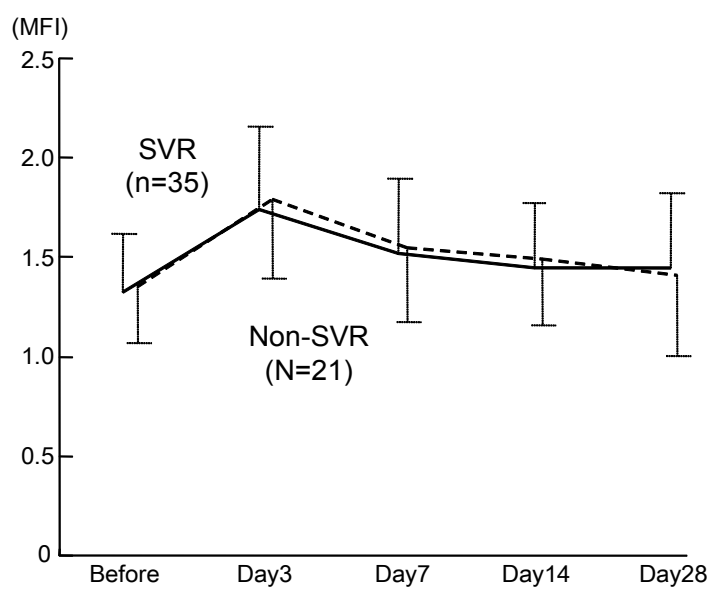

Figure 4a: The solid line shows mean IFNAR-2 expression by peripheral blood Mo (+ S.D.) in patients with IL-28 genotype TT who achieved sustained virologic response (SVR), and the dotted line shows IFNAR-2 expression by Mo (- S.D.) in patients with IL-28 genotype TT who did not achieve SVR (non-SVR)

\section{Discussion}

The present study demonstrated that clinical background did not differ between patients treated with PEG-IFN alpha-2a and with PEGIFN alpha- $2 \mathrm{~b}$ in combination with RBV. Although biochemical activity and IFN-induced gene transcripts are reported to be different between patients treated with PEG-IFN alpha-2a and those treated with PEGIFN alpha-2b [10], IFNAR-2 expression by peripheral blood Mo did not differ between the 2 groups.

It is not so easy to observe serial changes in IFNAR-2 expression in the liver after combination therapy with PEG-IFN and RBV in CHC patients. As hepatic expression of IFNAR-2 and its expression by peripheral blood mononuclear cells are reported to be correlated [11], it may be valuable to observe serial changes in receptor expression on peripheral blood Mo. It is also thought that assessing expression of the functional IFN receptor is useful, because IFN receptor protein located

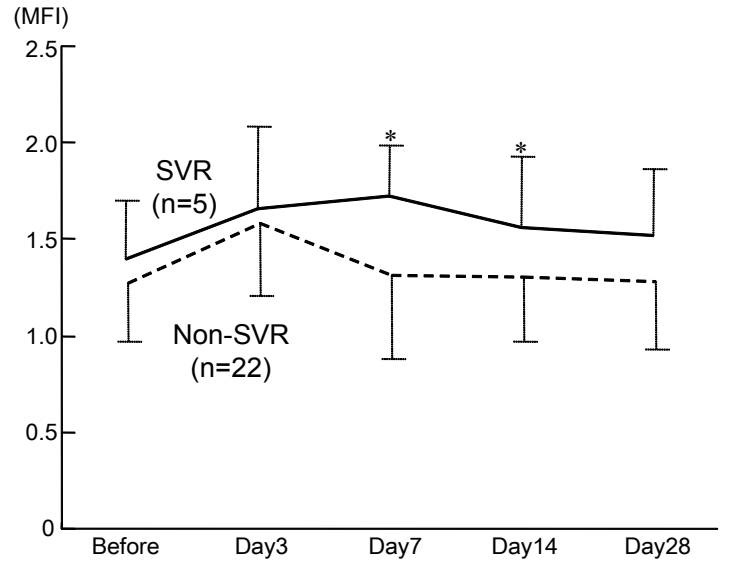

Figure 4b: The solid line shows mean IFNAR-2 expression by peripheral blood Mo (+ S.D.) in patients with IL-28 genotype TG who achieved the SVR, while the dotted line shows IFNAR-2 expression by Mo (- S.D.) in patients with IL-28 genotype TG who were non-SVR.

*: Significant difference $(P<0.05)$ between SVR and non-SVR patients with IL28 genotype TG.

on the cell membrane is functional, but intracellular receptor protein is not. Flow cytometry makes it possible to determine the amount of a particular receptor protein expressed on the surface of peripheral blood Mo in CHC patients.

In the present study, although IFNAR-2 expression by peripheral blood Mo was consistently higher in patients with IL-28 genotype TT than in patients with IL-28 genotype TG, statistical significance was not reached. However, a significant difference was seen between EVR and non-EVR patients, and between SVR and non-SVR patients with IL-28 genotype TG. In contrast, a significant difference was not seen between SVR and non-SVR patients with IL-28 genotype TT.

The mapped region (19q13) encodes 3 cytokine genes (IL-28A, IL$28 \mathrm{~B}$, and IL-29) that belong to the IFN-lambda (also known as type 3 IFN) family induced by viral infection and has antiviral activity [12]. IFN-lambdas, similar to IFN-alphas, are thought to stimulate the IFN signal pathway, which include phospholylation of the kinases JAK1 and Tyk2, activation of transcription factor complex containing STAT1, STAT2, and IFN regulatory factor 9, and up-regulation of a similar set of ISGs, after binding to heterodimeric receptor consisting of IL10R-beta and IL28R-alpha (IFN-lambdaR1) [13,14]. Finally, antiviral substances such as 2'-5'oligoadenylate synthetase, PKR, MxA and IL-8 are induced $[15,16]$.

In the present study, EVR was achieved in almost all patients (98\%) (1 patient did not show EVR), and SVR was achieved in 35 of 56 patients (63\%) with IL-28 genotype TT. However, the rates of EVR and SVR were low in patients with IL-28 genotype TG (56\% and 19\%, respectively). Recent reports have suggested that non-responder genotypes (TG or GG) in rs8099917 are associated with higher expression of ISGs in the liver prior to antiviral treatment and ultimately treatment failure [17]. Ahlenstiel et al. advocated a model for the role of IL-28B polymorphisms in chronic HCV infection [18]. According to the model, induction of ISGs is most likely driven by low-level expression of endogenous IFN, and the IL-28B non-responder genotype is associated with strong ISG induction [17]. When treated with IFN-alpha, this leads to diminished ISG [18] and IL-28B induction. In these patients, ISG and therefore IFN response are further impaired due to the activation of IFN inhibitory 
Citation: Ishii K, Shinohara M, Kanayama K, Kogame M, Shiratori M, et al. (2012) Interleukin-28B Genetic Variants and Peripheral Blood Interferon Receptor 2. J Blood Lymph 2:108. doi:10.4172/2165-7831.1000108

pathways secondary to the strong ISG induction [19]. From our results, it is hypothesized that patients with IL-28 genotype TG only develop EVR and SVR when ISGs are further induced through IFNARs that are up regulated by therapy with PEG-IFN and RBV.

In conclusion, flow cytometry showed that IFNAR-2 expression by peripheral blood Mo may be related to efficacy of PEG-IFN and RBV, when $\mathrm{CHC}$ patients with genotype $1 \mathrm{~b}$ and high viral loads possessed a poor-response IL-28B variant (genotype TG in rs8099917). Further studies may lead to a better understanding of the pathophysiological roles of IFNAR-2 in CHC patients with genotype $1 \mathrm{~b}$ and high viral load receiving PEG-IFN and RBV combination therapy.

\section{References}

1. Manns MP, McHutchinson JG, Gordon SC, Rustgi VK, Shiffman M, et al. (2001) Peginterferon alfa-2b plus ribavirin compared with interferon alfa- $2 b$ plus ribavirin for initial treatment of chronic hepatitis $\mathrm{C}$ : a randomized trial. Lancet 358: 958-965

2. Fried MW, Shiffman ML, Reddy KR, Smith C, Marinos G, et al. (2002) peginterferon alfa-2a plus ribavirin for chronic hepatitis $C$ virus infection. $N$ Engl I Med 347: 975-982.

3. Tanaka Y, Nishida N, Sugiyama M, Kurosaki M, Matsuura K, et al. (2009) Genome-wide association of IL28B with response to pegylated interferon-alpha and ribavirin therapy for chronic hepatitis C. Nat Genet 41: 1105-1109.

4. Ishii K, Shinohara M, Sawa M, Kogame M, Higami K et al. (2010) Interferon alpha receptor 2 expression by peripheral blood monocytes in patients with a high viral load of hepatitis $C$ virus genotype 1 showing substitution of amino acid 70 in the core region. Intervirology 53: 105-110.

5. Knodell RG, Ishak KG, Black WC, Chen TS, Craig R, et al. (1981) Formulation and application of a numerical scoring system for assessing histological activity in asymptomatic chronic active hepatitis. Hepatology 1: 431-435.

6. Desmet VJ, Gerber M, Hoofnagle JH, Manns M, Scheuer PJ (1994) Classification of chronic hepatitis: diagnosis, grading and staging. Hepatology 19: $1513-1520$.

7. Ohnishi Y, Tanaka T, Ozaki K, Yamada R, Suzuki H, et al. (2001) A highthroughput SNP typing system for genome-wide association studies. J Hum Genet 46: 471-477.
8. Suzuki A, Yamada R, Chang X, Tokuhiro S, Sawada T, et al. (2003) Functional haplotypes of PADI4, encoding citrullinating enzyme peptidylarginine deiminase 4, are associated with rheumatoid arthritis. Nat Genet 34: 395-402.

9. Tochizawa S, Akamatsu S, Sugiyama Y, Muraguchi M, Ohmoto Y, et al. (2004 A flow cytometric method for determination of the interferon receptor IFNAR2 subunit in peripheral blood leukocyte subsets. J Pharmacol Toxicol Method 50: 59-66.

10. Silva M, Poo J, Wagner F, Jackson M, Cutler D, et al. (2006) A randomized trial to compare the pharmacokinetic, pharmacodynamic, and antiviral effects of peginterferon alfa- $2 \mathrm{~b}$ and peginterferon alfa-2a in patients with chronic hepatitis C (COMPARE). J Hepatol 45: 204-213.

11. Yamaguchi Y, Hino K, Fujiwara D, Ren F, Katoh Y, et al. (2002) Expression of type I interferon receptor in liver and peripheral blood mononuclear cells in chronic hepatitis C patients. Dig Dis Sci 47: 1611-1617.

12. Ank N, West H, Bartholdy C, Erikson K, Thomsen AR, et al. (2006) Lambda interferon (IFN-lambda), a type III IFN, is induced by viruses and IFNs and displays potent antiviral activity against select virus infections in vivo. J Viorol 80: 4501-4509.

13. Kotenko SV, Gallagher G, Baurin VV, Lewis-Antes A, Shen M, et al. (2003) IFNlambda mediate antiviral protection through a distinct class II cytokine receptor complex. Nat Immunol 4: 69-77.

14. Li M, Liu X, Zhou Y, Su SB (2009) Interferon-lambda: the modulators of antivirus, antitumor, and immune response. J Leukoc Biol 86: 23-32.

15. Chen X, Bhandari R, Vinkemeier U, Van Den Akker F, Darnell JE Jr, et al (2003) A reinterpretation of the dimerization interface of the $\mathrm{N}$-terminal domains of STATs. Protein Sci 12: 361- 365.

16. Kisseleva T, Bhattacharya S, Braunstein J, Schindler CW (2002) Signaling through the JAK/STAT pathway, recent advances and future challenges. Gene 285: $1-24$

17. Honda M, Sakai A, Yamashita T, Nakamoto Y, Mizukoshi E, et al. (2010) Hepatic ISG expression is associated with genetic variation in IL28B and the outcome of IFN therapy for chronic hepatitis C. Gastroenterology 139: 499-509.

18. Ahlenstiel G, Booth DR, George J (2010) IL28B in hepatitis C virus infection: translating pharmecogenomics into clinical practice. J Gastroenterol 45: 903910.

19. Feld JJ, Nanda S, Huang Y, Chen W, Cam M, et al. (2007) Hepatic gene expression during treatment with peginterferon and ribavirin: Identifying molecular pathways for treatment response. Hepatology 46: 1548-1563. 